\title{
IMPRISONMENT FOR IUU FISHING IN INDONESIA'S EXCLUSIVE ECONOMIC ZONE: WHY IT SHOULD NOT BE IMPOSED
}

\author{
Alfons Zakaria \\ Fakultas Hukum Universitas Brawijaya Malang \\ Email: alfons@ub.ac.id
}

\begin{abstract}
Abstrak
Pasal 73 ayat (3) Konvensi Hukum Laut menekankan bahwa "hukuman yang dijatuhkan oleh negara pantai terhadap pelanggaran peraturan perundang-undangan perikanan di zona ekonomi eksklusif tidak boleh mencakup penjara, jika tidak ada perjanjian sebaliknya antara negara-negara yang terkait, atau bentuk hukuman badan lainnya". Namun, Pasal 93 Undang-undang Nomor 31 Tahun 2004 tentang Perikanan, sebagaimana diubah oleh Undang-undang Nomor 45 Tahun 2009, memberlakukan sanksi pidana penjara terhadap pelaku penangkapan ikan secara illegal di ZEE Indonesia. Di sisi lain, Indoensia adalah negera peserta konvensi dan telah meratifikasi Konvensi Hukum Laut. Sehingga Indonesia seharusnya tunduk terhadap seluruh ketentuan yang ada dalam konvensi. Pertanyaan yang timbul adalah apakah ini berarti Indonesia menggunakan kedaulatannya di ZEE? Tulisan ini melihat bahwa penerapan saksi pidana di ZEE adalah bertentangan tidak hanya terhadap peraturan perundang-undangan yang ada di Indonesia tetapi juga hukum laut internasional.
\end{abstract}

Kata kunci: hukuman penjara, ZEE, kedaulatan dan hak berdaulat

\section{Abstrack}

Article 73(3) of LOSC emphasizes that "Coastal State penalties for violations of fisheries laws and regulations in the exclusive economic zone may not include imprisonment, in the absence of agreements to the contrary by the States concerned, or any other form of corporal punishment." Article 93 of the Indonesian Fisheries Act Nomor 312004 as revised by the Act Nomor 45 2009, however, imposes imprisonment for IUU fishing committed in the Indonesian EEZ. It can be seen that there is a clear contradiction in provisions between Article 93 of the Act Nomor 312004 and Article 73(3) of the LOSC. On the other side, Indonesia is a state party of this convention and has ratified the convention. Thus, Indonesia should comply with the provisions in the LOSC. The question is has Indonesia exercised its sovereignty over the EEZ? This paper argues that the implementation of imprisonment in Indonesian EEZ contradicts both Indonesian laws and international law of the sea.

Key words: imprisonment, EEZ, sovereignty and sovereign rights

\section{Acknowledgment}

Indonesia successfully advocated the archipelagic concept in the Third United Nations Conference on the Law of the Sea (UNCLOS) in 1982. This event became the most significant development of the archipelagic regime to be internationally recognised. Indonesia, previously, started this effort by presenting the Djuanda Declaration in 1957, which emphasizes that the country comprising around 17,500 islands, has its own special uniqueness in territory and should be considered as a single unit. ${ }^{1}$ Therefore, this international recognition of the archipelagic principle, resulted in the enlargement of the Indonesian terri-

1 Clive Schofield and I Made Andi Arsana, 'Closing the loop: Indonesia's revised archipelagic baselines system', Australian Journal of Maritime and Ocean Affairs, Volume 1 (2), 2009, p. 57. 
torial sea area, where this significantly increased the country's marine resources.

Indonesia then produced certain laws to manage its marine resources. There are four main laws that regulate any activities conducted on all Indonesian maritime zones, namely the Indonesian Exclusive Economic Zone Act Nomor 5 1983, the Act Nomor17 1985 on the Ratification of United Nations Convention on the Law of the Sea 1982, the Indonesian Waters Act Nomor 61996 and the Fisheries Act Nomor 312004 as revised by the Fisheries Act Nomor 45 2009. ${ }^{2}$ These legislations were enacted after Indonesia signatured the United Nations Convention on the Law of the Sea (LOSC) 1982, and thus they merely emphasise the provisions of the LOSC. The Indonesian EEZ Act adopts and restates the provisions of the convention related to the rights of coastal State in the EEZ, although it does not clearly state that Indonesia recognises the LOSC. Act Nomor 171985 was the key for national legal standing to adopt the LOSC as national law. It can be said that the convention and all provisions of the convention are nationally accepted. Similarly, the Indonesian Waters Act Nomor 61996 reemphasises the provision on the convention related to Indonesian sea territory, the archipelagic baseline and innocent passage. The Fisheries Act Nomor 312004 regulates fishery and research activities conducted in Indonesian maritime zones.

However, in practice, these legislations are not apparently followed by sufficient management of the marine resources, particularly in maritime surveillance, enforcement and security management. ${ }^{3}$ As a result, Indonesia has recently suffered from the increase of illegal, unregulated, and unreported (IUU) fishing. ${ }^{4}$ IUU fishing becomes a substantial problem, ${ }^{5}$ because it has seriously affected not only the Indonesian economy but also fishermen and national fisheries. ${ }^{6}$ Authori- ties believed that this is because the Fisheries Act Nomor 312004 did not have sufficient provisions to control and anticipate the advancement of technology in fisheries, nor it has sufficient legal standing for managing the exploration and exploitation of marine resources. ${ }^{7}$ For example, IUU fishing activities in the Celebes Sea, where this area is included in the Indonesian EEZ, are conducted mostly by Philippine-flagged vessels. ${ }^{8}$ In response to this situation, Indonesia then attempted to combat IUU fishing by modifying the law.

Subsequently, several provisions in the Fisheries Act Nomor 312004 were changed by Act Nomor 45 2009. Three essential areas were revised, namely (i) legal monitoring and enforcement in criminal investigation and punishment; (ii) management on fishery conservation and fishing licence; and (iii) expanding court jurisdiction on all Indonesian maritime zones. ${ }^{9}$ The most controversial change was the implementation of imprisonment for IUU fishing committed in both Indonesian sea territory and exclusive economy zone (EEZ).$^{10}$ Article 93 of the Fisheries Act Nomor 31 2004 was revised to be read, in general translation, as any person who operates a foreign-flag vessel in the Indonesian EEZ and does not have in possession of fishing licence shall be punished by a maximum of six years imprisonment and IDR 2 billion.

The United Nations Convention on the Law of the Sea (LOSC) 1982, on the other hand, underlines that costal State penalties for violations of fisheries laws and regulations in its exclusive economic zone may not include imprisonment or any other form of corporal punishment. Article 73(3) of LOSC states that "Coastal State penalties for violations of fisheries laws and regulations in the exclusive economic zone may not include imprisonment, in the absence of agreements to

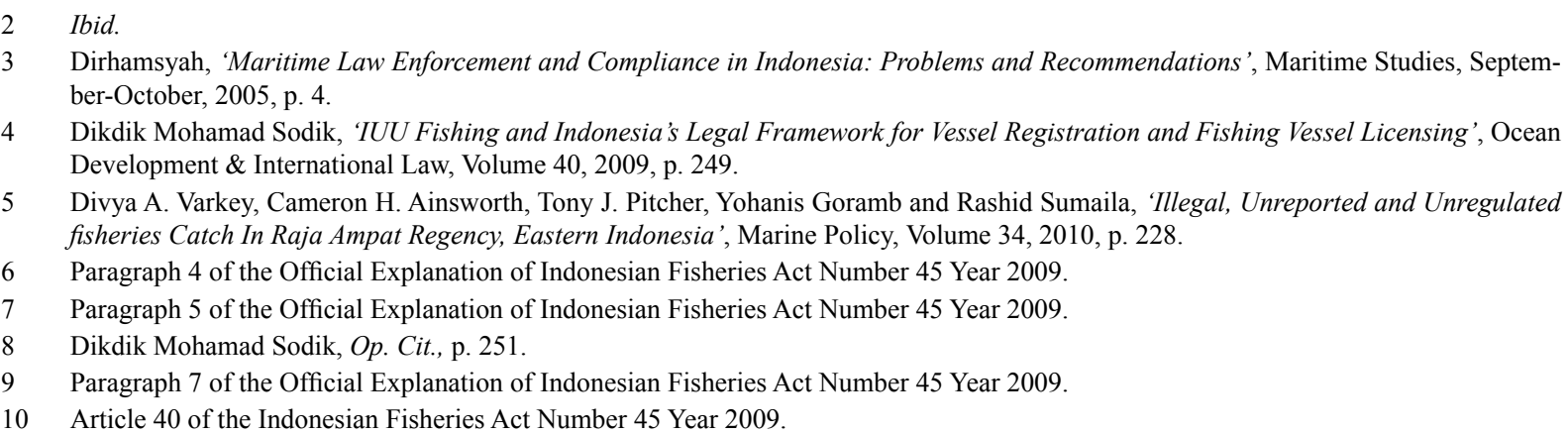


the contrary by the States concerned, or any other form of corporal punishment." It can be seen, unless there is an agreement, imprisonment or other corporal punishments for any violation of fisheries laws in the EEZ must not be imposed by the coastal State.

Indonesia as a state party of this convention should comply with the provision in the LOSC. Imprisonment should not be imposed in Indonesian EEZ. Therefore, there is a clear contradiction in provisions between Article 93 of the Act Nomor 312004 and Article 73(3) of the LOSC. A contradiction also appears in the national stage, because the Act Nomor 171985 declares that it had ratified the LOSC. This means that Indonesia adopted all provisions under the LOSC to be implemented on its national authority.

Disputes between Indonesia and other states will be simply created because article 73(3) of the LOSC provides a very clear statement. Other states may argue that Indonesia must not enforce legislation in its EEZ where that legislation contradicts the convention. An appropriate dispute settlement under international laws is therefore needed to ensure that this dispute will be resolved peacefully.

This paper considers whether the implementation of imprisonment in the Indonesian EEZ contradicts both national legislations and the LOSC, and how LOSC provides dispute settlement mechanisms if a conflict appears related to the implementation of imprisonment between Indonesia and other states. This paper will initially examine the revised Article 93 of the Indonesian Fisheries Act which contradicts national legislations. There are at least three main legislations that provide provisions opposing the revised Article 93, namely the Indonesian Exclusive Economic Zone Act Nomor 5 1983, the Act Nomor17 1985 on the Ratification of the United Nations Convention on the Law of the Sea 1982, and the Indonesian Waters Act Nomor 6 1996. This paper then describes that the revised Article 93 of the Act Nomor 312004 also contradicts the LOSC. In this part, it will analyse the differences between sovereignty and sovereign rights based on the provisions of the LOSC. This part also will briefly examine the provisions of UN Fish Stocks Agreement ${ }^{11}$ related to sanctions against IUU fishing. Finally, this paper will describe types of dispute settlement mechanisms that can be established to deal with the conflict between Indonesia and other state related to the implementation of imprisonment on Indonesian EEZ. This paper argues that the implementation of imprisonment in Indonesian EEZ contradicts both Indonesian laws and international law of the sea. Indonesia only has sovereign rights in its EEZ and sovereign rights differ from sovereignty. Thus, Indonesia has no jurisdiction to impose imprisonment in its EEZ.

\section{Analize}

\section{a. General Principles on Fishing Rights}

Basically, every person could fish in the sea, because fisheries are a common natural resource property and thus fish in the sea are not owned by anyone. From this notion, there are at least four consequences where the regulations of marine fisheries are concerned, namely:

1. A tendency for fish stocks to be fished above biologically optimum levels;

2. A tendency for more fishermen to engage in a fishery than is economically justified;

3. A likelihood of competition and conflict between different groups of fishermen;

4. The necessity for any regulation of marine fisheries to have a substantial international component. ${ }^{12}$

This means that the rising human population in the world increases the need of fish for human consumption, and thus fisheries will be enlarge. Then, the rising number of fishermen leads to an increasing number of fish taken, which results in the reduction of fish stock. ${ }^{13}$ In extreme cases the stock can even collapse. Additionally, the use of sophisticated technology for meeting this higher demand through more efficient fishing methods, creates greater adverse effects on fish stock. ${ }^{14}$

\footnotetext{
11 Agreement for The Implementation of The Provisions of The United Nations Convention on The Law of The Sea of 10 December 1982 Relating to The Conservation and Management of Straddling Fish Stocks and Highly Migratory Fish Stocks.

12 R. Robin Churchill and A. Vaughan Lowe, The Law of the Sea, Manchester, Manchester University Pres, 1999 , p. 281.

13 Dikdik Mohamad Sodik, 'Non-legally Binding International Fisheries Instruments and Measures to Combat Illegal, Unreported and Unregulated Fishing', Australian International Law Journal, Volume 15, 2008, p. 130.

14 Kevin W. Riddle, Illegal, 'Unreported, and Unregulated Fishing: Is International Cooperation Contagious?', Ocean Development \&
} International Law, Volume 37, 2006, p. 265. 
Accordingly, the coastal State regulations related to the control and management fishing is required, because illegal and unregulated fishing will generally lead to overfishing. ${ }^{15}$ Overfishing has become a major worldwide problem. ${ }^{16}$

Many costal states have produced certain regulations related to the controlling of illegal unreported and unregulated (IUU) fishing. From all the coastal State that provide national legislation related to regulating the exploration and exploitation of their EEZ:

1. The majority of the legislations clearly reproduce the substance of the provisions of the convention granting sovereign rights;

2. A relatively small number of states have adopted legislations which clearly and fully acknowledge the limitation placed upon their sovereign rights by the convention;

3. A further group of states have produced legislations which state only brief references to duties of conservation and optimum utilisation of fish stock. ${ }^{17}$

Indonesia apparently is a state that only provides legislation adopting and reproducing the provisions from the LOSC related to its sovereign rights. All main legislations (the Indonesian Exclusive Economic Zone Act Nomor 5 1983, the Act Nomor17 1985 on the Ratification of United Nations Convention on the Law of the Sea 1982, the Indonesian Waters Act Nomor 61996 and the Fisheries Act Nomor 31 2004) only restate or emphasise the provisions in the LOSC. On the other hand, this means that Indonesia complies with the convention by implementing the provisions to national authority.

However, the enactment of the Act Nomor 45 2009 where it revises some provisions in the Fisheries Act Nomor 31 2004, has made a fundamental change. Article 93 of the Indonesian Fisheries Act, where imprisonment is imposed in Indonesian EEZ, indicates not only that the article contradicts other national legislations, but also it does not comply with Article 73(3) of the LOSC.

\section{b. Revised Article 93 of the Fisheries Act contradicts other national laws}

In this part, it will be shown that revised
Article 93 of the Fisheries Act contradicts all Indonesian main laws regulating any activities conducted on all Indonesian maritime zones, namely the Indonesian Exclusive Economic Zone Act Nomor 5 1983, the Act Nomor 171985 on the Ratification of United Nations Convention on the Law of the Sea 1982, the Indonesian Waters Act Nomor 61996 and the Fisheries Act Nomor 31 2004. As explained above, generally speaking, these legislations only restate and emphasise the provisions in the LOSC.

\section{c. The Indonesian Exclusive Economic Zone Act Nomor 51983}

From the beginning, Indonesia has indicated that it acknowledges sovereign rights over its EEZ. This can be seen in Article 4(1) of the Indonesian EEZ Act where it similarly describes Article 55(1) of the convention. It recognizes that Indonesia has two kinds of power. Firstly, Indonesia has sovereign rights in its EEZ for exploring and exploiting, conserving and managing the living or non-living resources in waters superjacent to the seabed and of the seabed and its subsoil, and other activities for the economic exploitation and exploration of the zone, such as the production of energy from the water, currents and winds. Secondly, Indonesia has jurisdictional rights over specific activities, namely the establishment and use of artificial islands, installations and structures, marine scientific research, and the protection and preservation of the marine environment. Moreover, this Act acknowledges that Indonesia also has obligations over its EEZ that are described under the LOSC, such as the obligation to have due regard for the rights of other States, where they have freedoms of navigation and overflight as well as the laying of submarine cables and pipelines.

Furthermore, related to the criminal law enforcement in the EEZ, Article 13 of this EEZ Act states that Indonesia has the rights to arrest and detain any vessel or crew that has allegedly violated Indonesian laws in the EEZ. The punishment for violations under this Act, however, is a fine of IDR 225 million. There is no imprisonment or other corporal punishment that are regulated under this Act.

15 R. Robin Churchill, Op. Cit., p. 281.

16 Laurence Blakely, 'The End of The Viarsa Saga and The Legality of Australia's Vessel Forfeiture', Pacific Rim Law \& Policy Journal, Volume 17 (3), 2008, p. 680.

17 E. D. Brown, The International Law of the Sea, Hants, Darthmouth Publishing, 1994, p. 225. 
This means therefore that the EEZ Act complies with the LOSC. It recognises that in the EEZ, Indonesia only has sovereign rights and obligations to have due regard for the rights of other States. It also fulfils the Article 73(3) of the LOSC where imprisonment or other corporal punishments are not imposed in the EEZ.

\section{d. The Act Nomor17 1985 on the Ratification of United Nations Convention on the Law of the Sea 1982}

The LOSC became an important achievement and essential international instrument for Indonesia because by the LOSC, international law acknowledges the archipelagic state regime for the first time. ${ }^{18}$ The ratification of the LOSC through this Act has become a significant key for the implementation of the LOSC in Indonesia's national laws. Indonesia declared that all provisions of the LOSC are fully accepted to be national regulations. It has been internationally accepted that ratification of particular conventions by a state means that the state adopts the convention as a national regulation. Moreover, the sovereign rights in the EEZ are included as the main point in the LOSC, which is pronounced by Indonesia through this Act. Through this ratification, Indonesia then recognises that Article 73(3) of the LOSC is also accepted. In other words, imprisonment or other corporal punishments will not be imposed in Indonesian EEZ.

e. The Indonesian Waters Act Nomor 61996

This Indonesia Waters Act highlights that Indonesia is an archipelagic state and thus has exclusive rights related to the archipelagic water. This Act also describes how to measure Indonesian sea territory as an archipelagic state based on Article 47 of the LOSC; the right of innocent passage and the right of archipelagic sea lanes passage. The essential article is Article 4, which describes that Indonesia only has sovereignty over its territorial sea.
It has been generally accepted that in its territorial sea, a state has sovereignty which is an absolute right to make and enforce its laws. On the other hand, in the EEZ, the coastal State does not have sovereignty, and is therefore not allowed to make and enforce all its laws. The coastal State is only allowed to take particular action in the EEZ such as boarding, inspection, arrest and judicial proceedings. ${ }^{19}$ It can be seen that the Act does not recognise sovereignty over the EEZ. Sovereignty is only exercised on Indonesian sea territory included the archipelagic water.

\section{f. Revised Article 93 of the Fisheries Act Contradicts the LOSC}

As has been described above that revised Article 93 of the Indonesia Fisheries Act contradicts with other related national legislation. Other legislations acknowledge that Indonesia has sovereignty and sovereign rights over its maritime zones. This part will discuss the differences between sovereignty and sovereign rights according to the LOSC.

\section{g. Indonesia's Sovereignty Under the LOSC}

As a coastal and archipelagic state, Indonesian jurisdiction has been clearly described under provision of the LOSC. It extends to all maritime zones, from the territorial sea ${ }^{20}$ to the $\mathrm{EEZ}^{21}$. Indonesia's territorial sea extends to its bed, subsoil, the air space over the territorial sea ${ }^{22}$ and its archipelagic waters, ${ }^{23}$ and it has full sovereignty exercised over its territorial sea. The Indonesian EEZ is extended up to 200 miles from the baseline ${ }^{24}$ and the country is allowed to exercise its sovereign rights in relation to natural resources ${ }^{25}$ in its EEZ. In other words, based on the LOSC Indonesia has sovereignty and sovereign rights over its different maritime zones. In order to highlight the differences, both rights will be discussed below.

As a consequence of the sovereignty in territorial sea, it has generally been accepted that a state has absolute rights to make and enforce its

18 Paragraph 3 of the Official Explanation of The Act Number 17 Year 1985 on the Ratification of United Nations Convention on the Law of the Sea 1982.

19 Article 73(1) of the LOSC.

20 Article 2 of the LOSC.

21 Article 56 of the LOSC.

22 Article 2(2) of the LOSC.

23 Article 49(1) of the LOSC.

24 Article 57 of the LOSC.

25 Article 56(1) of the LOSC. 
laws in its territorial sea, and thus other states are not allowed to exercise their jurisdiction within this territory. However, the coastal state's right to exercise its jurisdiction in its territorial sea is not identical to that exercise on the land. ${ }^{26}$ This sovereignty is subject to the rights of all vessels to exercise innocent passage. ${ }^{27}$ Any ship of coastal or land-locked states, enjoys the right of innocent passage through the territorial sea. ${ }^{28}$ It allows for "continuous and expeditious" 29 passage through the territorial sea "so long as it is not prejudicial to the peace, good order or security of the coastal state" and it takes "place in conformity with this Convention and with other rules of international law"30. ${ }^{31}$ Passage of a foreign ship in the territorial sea will be considered as non-innocent if it is prejudicial to the peace, good order or security of the coastal state, because it engages in activities listed in Article 19(2) of the convention, such as using force against the sovereignty, exercising or practising weapons, acting wilful and serious pollution, and fishing.

Furthermore, Article 49 of the LOSC describes that an archipelagic state's sovereignty can be exercised in its archipelagic waters, where it extends to the waters enclosed by the archipelagic baselines drawn using certain measurements in accordance with Article 47, regardless of their depth or distance from the coast. An archipelagic state's sovereignty also extends to the air space over the archipelagic waters, as well as to their bed and subsoil, and the resources contained therein.

Moreover, Indonesia is allowed to exercise its criminal jurisdiction to any unlawful act committed in its territory. Although under Article 27 of the LOSC, there is no jurisdiction to arrest any person or conduct any investigation related to any crime committed on board a foreign ship during its passage, Indonesia has the right to take such actions limited in the following cases:

(a) if the consequences of the crime extend to the coastal State;

(b) if the crime is of a kind to disturb the peace of the country or the good order of the territorial sea;

(c) if the assistance of the local authorities has been requested by the master of the ship or by a diplomatic agent or consular officer of the flag State; or

(d) if such measures are necessary for the suppression of illicit traffic in narcotic drugs or psychotropic substances.

It can be seen that Indonesian sovereignty is allowed to be fully exercised in its territorial sea and limited by the rights of innocent passage, and its criminal jurisdiction is restricted on board a foreign ship which can be exercised only within limited circumstances. Further questions are what rights Indonesia can exercise in its EEZ and whether Indonesia has the right to impose imprisonment on the EEZ.

\section{h. Indonesia's Sovereign Rights under the LOSC}

The Exclusive Economic Zone (EEZ) is an area beyond and adjacent to the territorial $\mathrm{sea}^{32}$ which extends up to 200 miles from the baseline ${ }^{33}$. In other words, the EEZ's inner limit is the outer limit of the territorial sea and the outer limit is 200 nautical miles from the baseline. The EEZ constitutes a separate zone in its own right ('sui generis'), neither part of the territorial water nor of the high seas. ${ }^{34}$ The EEZ is a novel concept, ${ }^{35}$ where this area is a reflection of the aspiration of the developing states for economic development and their desire to obtain greater exploitation and exploration over the economic resources of their coasts. ${ }^{36}$ Almost all coastal States have claimed their EEZ, ${ }^{37}$ although there is no obligation under

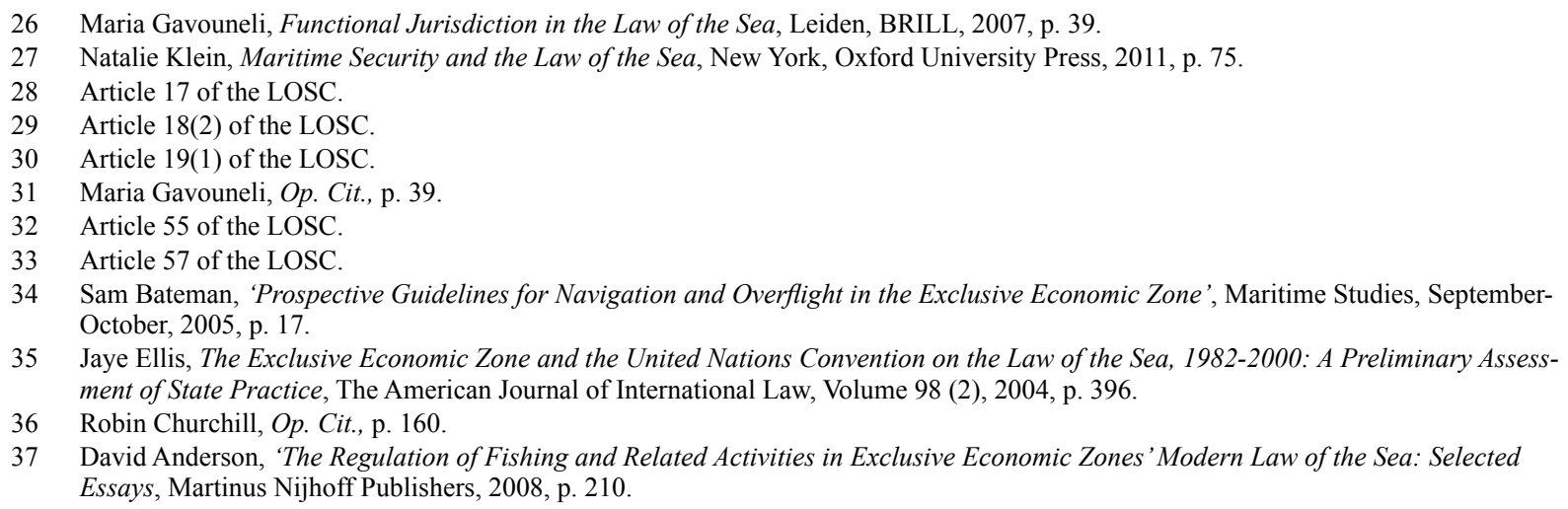


the LOSC for such States to exercise their rights to claim an EEZ. ${ }^{38}$

The baseline measurement of the EEZ, however, is not easy. In practice, many coasts are not straight. They often have islands, sandbanks, bays and harbours. Therefore, Section 2 Part II of LOSC provides guidance to regulate the measurement of baselines which influenced by a wide variety of geographical circumstances. One of the measurements is under Article 5, where it regulates that "the normal baseline for measuring the breadth of the territorial sea is the low-water line along the coast as marked on large-scale charts officially recognized by the coastal". The consequence of choosing the law-water line rather than the high-tide line is "to push the outer limit of the territorial sea and other zones seawards, particularly on coasts where there is an extensive tidal range". ${ }^{39}$ Other measurements are subject to particular condition such as reefs, river mouths, bays, ports, roadstead and low-tide elevation, which are described under Article 6-13 of the LOSC.

Moreover, as an archipelagic state, Indonesia can draw an archipelagic baseline around the archipelago. Article 47(1) of the LOSC describes that "an archipelagic State may draw straight archipelagic baselines joining the outermost points of the outermost islands and drying reefs of the archipelago". This baseline is then used to measure the breadth of the territorial sea, the contiguous zone, the exclusive economic zone and the continental shelf of archipelagic states. ${ }^{40}$ The drawing of the archipelagic baselines is based on a number of circumstances described by Article 47.

In the EEZ, the coastal states have been granted only two types of powers by LOSC. Firstly, they have sovereign rights for "exploring and exploiting, conserving and managing the natural resources, whether living or non-living, of the waters superjacent to the seabed and of the seabed and its subsoil, and with regard to other activities for the economic exploitation and exploration of the zone, such as the production of energy from the water, currents and winds". ${ }^{41}$ In other words, Article 55 grants the coastal state the sovereign rights only over (i) living resources in the EEZ water column; (ii) non-living resources in the water column and seabed and subsoil; and (iii) other activities for the economic exploitation and exploration of the zone, such as the production of energy from the water, currents and winds. ${ }^{42}$ This means that the coastal State have the right and responsibility to exploit, develop, manage and conserve all resources, such as fish, oil, gas, sand and gravel, nodules, minerals, sulphur, to be found in the waters, on the ocean floor and in the subsoil. ${ }^{43}$ Secondly, the coastal states also have jurisdictional rights over specific activities, namely the establishment and use of artificial islands, installations and structures, marine scientific research, and the protection and preservation of the marine environment. ${ }^{44}$

Although, the coastal states have such extensive rights, all states still have rights under the freedom of the high seas described in article 87 of the LOSC, except for the freedom of fishing which is the exclusive sovereign rights of the coastal States. ${ }^{45}$ All states, whether coastal or land-locked enjoy freedoms of navigation and over flight by aircraft and of the laying of submarine cables and pipelines. ${ }^{46}$ It can be seen that the LOSC has limited the exercise of the sovereign rights of the coastal state. The exercise of sovereign rights is not only less than sovereignty but also limited by the obligation to acknowledge specified rights of other states. ${ }^{47}$

The essential rule that the coastal state must concern related to sovereign rights is the "due regard" rule. ${ }^{48}$ This rule emphasises again that

38 Robin Churchill, Op. Cit., p. 161.

39 Ibid., 33.

40 Article 48 of the LOSC.

41 Article 56(1)(a) of the LOSC.

42 E. D. Brown, Op. Cit., p. 220.

43 Gunnar Kullenberg, 'The exclusive economic zone: some perspectives', Ocean \& Coastal Management, Volume 42, 1999 , p. 849.

44 Article 56(1)(b) of the LOSC.

45 Jon M. Van Dyke, 'Military Ships And Planes Operating in The Exclusive Economic Zone of Another Country', Marine Policy, Volume 28,2004 , p. 29 .

46 Article 58(1) of the LOSC.

47 David Anderson, Op. Cit., p. 211.

48 Mark J. Valencia and Kazumine Akimoto, 'Guidlines For Navigation and Overflight in The Exclusive Economic Zone’, Marine Policy, Volume 30, 2006, p. 705. 
sovereign rights are not absolute rights over the EEZ. Article 56(2) describes that in exercising its rights and performing its duties under this Convention in the EEZ, the coastal State must have due regard to the rights and duties of other States. These rights therefore will not mean absolutely exclusive for the costal State because their exercise is limited in certain cases by the obligation to share with other states. Then, the use of exclusive economic zone terms even sometime is more clearly than sovereign rights concerning exploration and exploitation of living resources. ${ }^{49}$

Moreover, Juda states that "it is important to note that Article 56 grants to the coastal state "sovereign rights" for designated purposes and not "sovereignty". ${ }^{50}$ In fact, that the EEZ differs from territorial sea and the high seas, and thus it is obviously clear that the costal state does not have any sovereignty over the EEZ. In addition, Brown states that the description of the EEZ as an Exclusive Economic Zone is misleading, because "sovereign rights are less than full sovereignty over the area, they are more than simply exclusive rights, in the sense that their scope must be extensively interpreted to include whatever powers are needed to ensure that the coastal state is able to enjoy its rights in full". ${ }^{51}$

Furthermore, related to the archipelagic regime, there is no certain right for archipelagic state in EEZ. The archipelagic state has the same rights with the costal state under the LOSC to exercise their rights. Generally, there are no longer any legal presumption concerning rights and jurisdiction in the EEZ, except the rights that are described in Articles 55, 56 and 58..$^{52}$ Indonesia, therefore, as a coastal state or an archipelagic state, has only sovereign rights over its EEZ, where the rights are limited by the obligation to share with other states.

Additionally, under the LOSC, there are two main sources of enforcement rights applying and operating in the EEZ, namely thematic cross-zonal provisions and EEZ-specific provisions. ${ }^{53}$ Firstly, the thematic cross-zonal provisions are applied as equally in the EEZ as they do in other sea zones, and they related to Hot Pursuit ${ }^{54}$, dumping ${ }^{55}$ and oil pollution ${ }^{56}$. The coastal State is granted to take certain measures against violations committed in its EEZ regarding Hot Pursuit, dumping and oil pollution. Secondly, the LOSC also grants the coastal State specific rights of enforcement power relating to the EEZ. Article 73(1) describes that in the exercise of sovereign rights to explore, exploit, conserve and manage the living resources, the coastal State is allowed to take measures, including boarding, inspection, arrest and judicial proceedings. Article 220(3) also permits the coastal State, with 'clear grounds for believing' that a vessel has violated pollution regulations in the EEZ, 'require the vessel to give information regarding its identity and port of registry its last and its next port of call and other relevant information required to establish whether a violation has occurred'. All these rights, however, do not mean that the LOSC provides sovereignty for the coastal State in its EEZ. They are given by the Convention merely to support sovereign rights exercised in the EEZ under guidance by the LOSC.

According to the discussion above, it can be understood that the notion of sovereign rights differs from sovereignty. Although, it has been argued that "the existence of the sovereign rights creates presumption of sovereignty for the coastal States which would supersede a jurisdictional claims by another State", sovereign rights indicate less than sovereignty. ${ }^{57}$ Sovereign rights only can be exercised on the EEZ that has been proclaimed to the world. In contrary, sovereignty can be exercised on the territorial sea which constitutes attributes of the State $a b$ inition. ${ }^{58}$

49 E. D. Brown, Op. Cit., p. 234.

50 Lawrence Juda, 'The exclusive economic zone: Compatibility of national claims and the UN convention on the law of the sea', Ocean Development \& International Law, Volume 16 (1), 1986, p. 5.

51 E. D. Brown, Op. Cit., p. 220.

52 Ibid.

53 Rob Mclaughlin, 'Coastal state use of force in the EEZ under the Law of the Sea Convention 1982', University of Tasmania Law Review, Volume 18 (1), 1999, p. 14.

54 Article 111 of the LOSC.

55 Article 210 of the LOSC.

56 Article 221 of the LOSC.

57 Maria Gavouneli, Op. Cit., p. 64.

58 Ibid., 65 
Therefore, the implementation of imprisonment indicates inconsistency of Indonesian acts with international regulation, that is the LOSC. The LOSC provides sovereignty only in territorial sea and does not provide rights over the EEZ for the coastal State, except the sovereign rights. This means that revised Article 93 of the Fisheries Act not only contradicts Article 73(3) of LOSC, but also Indonesia may exercise its sovereignty over the EEZ.

\section{i. UN Fish Stocks Agreement}

Indonesia is a party to the LOSC and the UN Fish Stocks Agreement, but not to the FAO Compliance Agreement. ${ }^{59}$ As the party, Indonesia has the obligation to comply the provisions of the UN Fish Stock Agreement. In other words, this Agreement is binding upon Indonesia. This Agreement was made to ensure the long-term conservation and sustainable use of straddling fish stocks and highly migratory fish stocks through effective implementation of the relevant provisions of the LOSC. ${ }^{60}$ The Agreement represents an attempt in both codification and a progressive development of international law, because it offers the promise of substantial impact on the management of world fisheries. ${ }^{61}$

Under this Agreement, obligations and rights have been granted for Indonesia as the state party. In the exercise Indonesia's sovereign rights, Indonesia must apply mutatis mutandis the general principles under Article 5, ${ }^{62}$ where it must take measures to prevent or eliminate overfishing and excess fishing capacity and ensure that levels of fishing effort do not exceed those commensurate with the sustainable use of fishery resources. ${ }^{63}$ Moreover, in the cases when violations occur, Indonesia is able to conduct an investigation and judicial proceeding, and impose a sanction in respect of the violation have been complied. ${ }^{64}$

Related the sanction, the Agreement does not provide a clear type of sanction that could be imposed by the state parties. Article 19(2) emphasises that "sanctions applicable in respect of viola- tions shall be adequate in severity to be effective in securing compliance and to discourage violations wherever they occur and shall deprive offenders of the benefits accruing from their illegal activities". Nevertheless, this does not mean that there is no limitation on types of sanction when the state parties will impose them. Article 4 of this Agreement states that the Agreement must be interpreted and applied in the context of and in a manner consistent with the LOSC. On the other side, Article 73(3) of LOSC states that penalties for violations of fisheries laws and regulations in the exclusive economic zone may not include imprisonment or any other form of corporal punishments. Therefore, this can be understood that the implementation of sanction under UN Fish Stocks Agreement is subject to the LOSC, where imprisonment or any other form of corporal punishments must not be imposed.

\section{j. Dispute settlements}

The contradiction between revised Article 93 of the Indonesian Fisheries Act and other national legislation and the LOSC will highly create disputes both between Indonesia and an individual, and between Indonesia and other States or non State entities. An individual may seek the settlement of the dispute through domestic law mechanisms. Indonesian laws provide legal procedures for a citizen to seek a judicial review to the Constitutional Court for domestic laws. The LOSC also provides several mechanisms to settle a dispute Indonesia and other States or non State entities.

The dispute resolution provisions of the LOSC are described in Part XV and related annexes. Section 1 (General Provisions) of Part $\mathrm{XV}$ provides the fundamental principles related to dispute settlements. Part XV requires State parties to settle their disputes by the peaceful means indicated in Article 33 paragraph 1 of the Charter of the United Nations. ${ }^{65}$ Related to the dispute resolutions provided by the LOSC, Article 280 states

59 Dikdik Mohamad Sodik, Op. Cit., p. 249

60 Article 2 of the UN Fish Stocks Agreement.

61 Lawrence Juda, 'The United Nations Fish Stocks Agreement', in Olav Schram Stokke and Øystein B. Thommessen (eds.), Yearbook of International Co-operation on Environment and Development, London, Earthscan Publications, 2001, p. 54.

62 Article 3(2) of the UN Fish Stocks Agreement.

63 Article 5(h) of the UN Fish Stocks Agreement.

64 Article 19(1) of the UN Fish Stocks Agreement.

65 Article 279 of the LOSC. 
that nothing in this Part hinders the right of States parties to settle a dispute between them by peaceful means of their own choice. Therefore, State parties are not bound by the dispute resolutions provided by the LOSC, and free to choose other dispute settlement mechanisms. The settlements under Part XV apply only where no settlement has been reached by settlements that have been chosen by the State parties, and the agreement between the parties does not exclude any further procedure. ${ }^{66} \mathrm{It}$ is the prerogative of State parties to choose which of provided procedures should be accepted for the settlement of disputes. ${ }^{67}$ Moreover, the settlements under Part XV could also be replaced, in the case that State parties have agreed through a general, regional or bilateral agreement which entails a binding decision. ${ }^{68}$

The first obligation for State parties is to proceed expeditiously and exchange of views regarding its settlement by negotiation or other peaceful means. ${ }^{69}$ Moreover, if the State parties to a dispute fail to reach a settlement through agreed procedures, one of them is allowed to invite other party or parties to submit the dispute to conciliation in accordance with the procedure under Annex V..$^{70}$ However, if there is no settlement that is reached after conducting recourse to Section 1 Part XV, State parties must refer to compulsory settlements under Section $2 .^{71}$

The provisions of Section 2, establishing compulsory and binding methods, were established to offer maximum flexibility for the State parties to a dispute, because not all disputes may be appropriate for the binding settlements. ${ }^{72}$ Section 2 provides flexibility for State parties to make a written declaration choosing one or more of the following compulsory settlements: ${ }^{73}$

a. the International Tribunal for the Law of the
Sea established in accordance with Annex VI;

b. the International Court of Justice;

c. an arbitral tribunal in relation to Annex VII; or

d. a special arbitral tribunal constituted in accordance with Annex VIII for one or more of the categories of disputes specified therein.

One of these procedures will be used if the State parties to a dispute agree to such procedure. The court or tribunal chosen under Article 287 has jurisdiction to promptly release a vessel or crew detained by a State party. ${ }^{74}$ Moreover, if there is still disagreement regarding these procedures, the State parties must submit the dispute only to arbitration in accordance with Annex VII. ${ }^{75}$ This arbitration also has jurisdiction in the case if the parties indicate a preference for two different bodies. ${ }^{76}$

It can be seen that the dispute settlement mechanisms provided by the LOSC has a lot of complexness. This seems because there was wide disagreement among State parties to use a simple method..$^{77}$ On the other hand, this complexity will encourage vast opportunities to settle a dispute among the State parties by peaceful means, such as diplomatic approaches.

\section{Conclusion}

From the discussions above, it can be conclude that revised Article 93 of the Indonesian Fisheries Act contradicts national legislations and the LOSC. The implementation of imprisonment under Article 93 constitutes an effort to exercise sovereignty over the EEZ. Other national legislations admit that the EEZ is not territorial sea, and thus sovereignty cannot be exercised in the EEZ. Moreover, the LOSC only grants sovereign rights

66 Article 281(1) of the LOSC.

67 Thomas A. Mensah, 'The Place of the International Tribunal for the Law of the Sea in the International System for the Peaceful Settlement of Disputes' in P. Chandrasekhara Rao and Rahmatullah Khan (eds) The International Tribunal For The Law of The Sea : Law and Practice, Hague, Kluwer Law International, 2001, p. 19.

68 Article 282 of the LOSC.

69 Article 283(1) of the LOSC.

70 Article 284 of the LOSC.

71 Article 286 of the LOSC.

72 Georgios I. Zekos, Competition or Conflict in The Dispute Settlement Mechanism of The Law of The Sea Convention, Hellenic Review of International Law, Volume 56, 2003, p. 154.

73 Article 287(1) of the LOSC.

74 E. D. Brown, 'Dispute settlement and the law of the sea: the UN Convention regime', Marine Policy, Volume 21, 1997, p. 20.

75 Ibid.

76 Article 287(3) of the LOSC.

77 Park Hee Kwon, The Law of the Sea and Northeast Asia, A challenge for Cooperation, Hague, Kluwer Law International, 2000, p. 114. 
to the coastal State in its EEZ, where the rights limited to exploring and exploiting, conserving and managing the natural resources. Article 73(3) of the LOSC also clearly states that imprisonment or other corporal punishments must not be imposed in the EEZ.

The attempt to combat IUU fishing over Indonesian EEZ by the implementation of such punishment then generates a question concerning its effectiveness. The question recently is difficult to be answered, because the implementation of that article is less than two years. On the other hand, a dispute related to the implementation will be undoubtedly created. The LOSC provides flexibility for State parties to a dispute to settle the dispute through various mechanisms that provided by the convention or informal procedures.

\section{REFERENCES}

\section{Book}

David Anderson, 2008 'The Regulation of Fishing and Related Activities in Exclusive Economic Zones' Modern Law of the Sea: Selected Essays, Martinus Nijhoff Publishers.

E.D. Brown, 1994, The International Law of the Sea, Hants, Darthmouth Publishing.

Lawrence Juda, 2001 'The United Nations Fish Stocks Agreement', in Olav Schram Stokke and Øystein B. Thommessen (eds.), Yearbook of International Co-operation on Environment and Development, London, Earthscan Publications.

Maria Gavouneli, 2007, Functional Jurisdiction in the Law of the Sea, Leiden, BRILL.

Natalie Klein, 2011, Maritime Security and the Law of the Sea, New York, Oxford University Press.

Park Hee Kwon, 2000, The Law of the Sea and Northeast Asia, A challenge for Cooperation, Hague, Kluwer Law International.

R. Robin Churchill and A. Vaughan Lowe, 1999, The Law of the Sea, Manchester, Manchester University Pres.

Thomas A. Mensah, 2001, 'The Place of the International Tribunal for the Law of the Sea in the International System for the Peaceful Settlement of Disputes' in P. Chandrasekhara Rao and Rahmatullah Khan (eds) The International Tribunal for the Law of the Sea : law andpractice,Hague, Kluwer Law International.

\section{Journal}

Clive Schofield and I Made Andi Arsana, 2009, 'Closing the loop: Indonesia's revised archipelagic baselines system', Australian Journal of Maritime and Ocean Affairs, Volume 1 (2).

David Freestone, Richard Barnes, and David Ong, 2010, The Law of the Sea, Progress and Prospects, Oxford Scholarship Online.

Dikdik Mohamad Sodik, 2009, 'IUU Fishing and Indonesia's Legal Framework for Vessel Registration and Fishing Vessel Licensing', Ocean Development \& International Law, Volume 40.

Dikdik Mohamad Sodik, 2008, 'Non-legally Binding International Fisheries Instruments and Measures to Combat Illegal, Unreported and Unregulated Fishing', Australian International Law Journal, Volume 15.

Dirhamsyah, 2005, 'Maritime Law Enforcement and Compliance in Indonesia: Problems and Recommendations', Maritime Studies, September-October.

Divya A. Varkey, Cameron H. Ainsworth, Tony J. Pitcher, Yohanis Goramb and Rashid Sumaila, 2010, 'Illegal, unreported and unregulated fisheries catch in Raja Ampat Regency, Eastern Indonesia', Marine Policy, Volume 34.

E. D. Brown, 1997, 'Dispute settlement and the law of the sea: the UN Convention regime', Marine Policy, Volume 21.

Georgios I. Zekos, 2003, Competition or Conflict in The Dispute Settlement Mechanism of The Law of The Sea Convention, Hellenic Review of International Law, Volume 56. 
Gunnar Kullenberg, 1999, 'The exclusive economic zone: some perspectives', Ocean $\&$ Coastal Management, Volume 42.

Jaye Ellis, 2004, 'The Exclusive Economic Zone and the United Nations Convention on the Law of the Sea, 1982-2000: A Preliminary Assessment of State Practice, The American Journal of International Law, Volume 98 (2).

Jon M. Van Dyke, 2004, Military ships and planes operating in the exclusive economic zone of another country', Marine Policy, Volume 28.

Kevin W. Riddle, Illegal, 2006, 'Unreported, and Unregulated Fishing: Is International Cooperation Contagious?', Ocean Development \& International Law, Volume 37.

Laurence Blakely, 2008, 'The End of The Viarsa Saga and The Legality of Australia's Vessel Forfeiture', Pacific Rim Law \& Policy Journal, Volume 17 (3).

Lawrence Juda, 1986, 'The exclusive economic zone: Compatibility of national claims and the UN convention on the law of the sea', Ocean Development \& International Law, Volume 16 (1) .
Mark J. Valencia and Kazumine Akimoto, 2006, 'Guidelines for navigation and overflight in the exclusive economic zone', Marine Policy, Volume 30.

Rob Mclaughlin, 1999, 'Coastal state use of force in the EEZ under the Law of the Sea Convention 1982", University of Tasmania Law Review, Volume 18 (1).

Sam Bateman, 2005, 'Prospective Guidelines for Navigation and Overflight in the Exclusive Economic Zone' Maritime Studies, Se ptember-October.

\section{Regulation}

Act Number 5 Year 1983 on Exclusive Economic Zone of Indonesia.

Act Number 17 Year 1985 on United Nations Convention on the Law of the Sea Racitification.

Act Number 6 Year 1996 on Indonesia Waters.

Act Number 31 Year 2004 jo. Act Number 45 Year 2009 on Fishery.

United Nations Fish Stocks Agreement. 